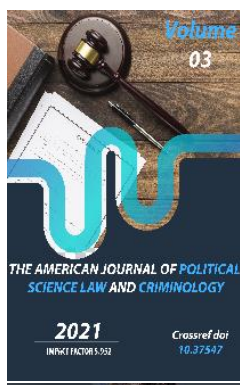

\title{
Electoral Function Of Political Parties: Theoretical And Legal Views
}

Bekov Ikhtiyor Rustamovich

PhD In Law , Associate Professor Of The Department Of Tashkent State Law University, Uzbekistan

Journal Website: http://usajournalshub.c om/index,php/tajpslc

Copyright: Original content from this work may be used under the terms of the creative commons attributes 4.0 licence.

\section{ABSTRACT}

The article examines the role of political parties in the electoral culture of society, electoral technologies, peculiarities of working with voters in the electoral process, the order, forms and methods of implementing the electoral functions of political parties. The author notes that in Uzbekistan not enough attention is paid to the use of the electoral functions of political parties, there are gaps in the legislation on this issue.

The author argues that the main direction of improving domestic practice and legal solutions to these issues is the effective use of information technology.

\section{KEYWORDS}

Political party, electorate, electoral function, electoral platform, program of a political party.

\section{INTRODUCTION}

According to international electoral standards and the experience of developed countries, there are different legal mechanisms for the direction, methods and forms of work of political parties with the electorate. These legal provisions and mechanisms should include measures to ensure the free expression of the will of citizens, the election of authorities, the 
restraint of state activities and the establishment of strong public control over them, the creation of equal opportunities and conditions for political forces.

The fundamental basis of these rules and mechanisms is the most democratic way of forming the optimal state power - elections.

The participation of political parties in the management of public affairs is the most effective way to involve them in the process of organizing public authorities, public administration and lawmaking.

The process of democratic formation of representative bodies of state power is largely associated with the growing role of political parties in the life of the state, the development of political diversity as the basis of the constitutional system. These three aspects are inseparable and complementary. Although Article 5 of the Law of the Republic of Uzbekistan "On Political Parties" prohibits the interference of the state and parties in each other's activities, it is the participation of political parties in elections that contributes to the development of constitutional political and ideological diversity.

Some scholars describe a political party as, on the one hand, a

"party-organization" and, on the other, a "party of voters." For example, according to $\mathrm{E}$. Downs, a party is "a group of people who want to run the state apparatus by holding positions in organized elections." [1. P. 3]

In developed countries, a lot of research has been done on political parties and their methods of working with the electorate, their forms. If we look at the research published in recent years, it should be noted that significant research has been conducted on the organic relationship between the political party and the electorate, the role of the party in the development of political pluralism in society.

In particular, Y. Mersel analyzed the dissolution of political parties, the termination of their activities is a problem that needs to be solved by internal democracy [2. P. 84-113], R.C.Wigton in his study considers the appropriateness of the programs and goals of existing political parties in the United States to the country's constitution, noting that the courts should repeal them if the programmatic goals or interests of political parties contradict the U.S. Constitution [3] ( In this case, the contradictions are not the parties opposed to the constitutional order, but the fact that their goals contradict the general constitutional principles - the author's comment).

The interests of the electorate of political parties have been analyzed not only in developed countries but also in African countries experiencing a process of democratic development. In particular, C. M. Fombad points out political parties as the main tool for solving the problems that arise in ensuring constitutionalism and the exercise of constitutional rights in Africa [4. P. 1-45].

In his study, R. Gabryszak analyzed the dynamics of changes in the positions of political parties in Poland in addressing the social issues of the electorate in each election year, and puts forward the view that these processes change in each election year in accordance with the level of socio-economic development [5. P. 95].

In recent years, a number of articles have been published on the legal status of political parties 
and especially their role in the development of the country.

In particular, O. Heath and A. Siegfeld, in their articles, assessed the variability of elections in India from time to time, the entry of political parties into these processes and the termination of their activities, and concluded that the existence of a political party depends on the interests of the electorate [6. P. 570].

It should be noted that the research conducted in the last century has put forward a number of fundamental ideas on the level of electoral effectiveness of political parties and its evaluation. In particular, K. Deshouer distinguishes between "electoral efficiency" measured by the number of votes and "political efficiency" measured by participation in government and leadership [7. P. 6] In agreement with the opinion of this researcher, we believe that it is important to keep in mind that these two efficiencies are inextricably linked. This is because "electoral efficiency" in turn serves to ensure "political efficiency" that governs government and provides political leadership.

K. Janda, a well-known expert in the field of partology, describes the functions of a political party as "an organization aimed at the open holding of public office by its representatives" [8. P. 32].

Indeed, political parties not only participate in the representation and protection of certain social interests, but their main task is to participate in the decision-making and implementation at the state level based on their electoral interests.

This participation depends in essence on the positions they hold in the representative bodies at the end of the election, and requires political parties to conduct ongoing research to improve the electoral efficiency. Therefore, the participation of political parties in elections is characterized by a majority in parliament, participation in the formation or formation of government, and the struggle for state power through elections.

The struggle of political parties for state power reflects their political competition. An important task of the parties is to turn the interests of individual citizens, social strata and interest groups into their common political interests. The most important political rights of citizens are realized through parties and electoral systems. Russian researcher E.A. Volkova notes that parties actively participate in or indirectly influence the mechanism of exercise of political power [9. P. 6].

Researchers studying the legal status and activities of political parties pay special attention to the electoral function of parties. At the same time, they make extensive use of a special method of scientific knowledge - a functional approach. Thus, some representatives of the functional approach describe the function of the party in a broad sense: "... to achieve a certain social or political goal" [10. P. 5] and in the narrow sense: "... the desire to expand the powers granted by the people, or part of them, to exercise political power through elections or in addition to elections, and to continue political governance" [11. P. 3-4].

The main function of political parties is to legitimize political activity, to seek mutual consent between different groups of society and the state, to coordinate social processes, to participate in the formation of democratic public authorities through elections. 
The latter function is also commonly referred to as the electoral function. Modern political parties that perform this function are becoming an important factor (element) of democratic electoral practice.

According to the scientific literature, the term electorate (Latin "elector" - voter, English "electorate" - a group of voters, the electoral corps) - means the total number of voters in a particular state, administrative-territorial unit or a constituency. In addition, this concept can also mean a deputy who represents a party, a voter who supports an elected official.

Hence, there is no single approach to the concept of electorate. According to the first approach, the term "electorate" refers to all voters. According to the second approach - the electorate - it is the voters of the party. In our opinion, the second interpretation corresponds to the essence of the category of "electorate". This view is based on an analysis of the practice of a number of foreign countries. In particular, "the electorate is the layer of voters who vote for the candidates of political parties and support the election of a representative of this party in government." Accordingly, the electorate is the supporters of a particular political party, the mass of voters who support it, i.e. the social base of the party.

Proponents of the electoral function $M$. Duverger, R. Katz, J. Lambert,

E. Leykman, R. Taagepera, M. Shugart, etc.) [12] fully link the political life of the party only with the electoral process, that is, with the legitimate participation of parties in the formation of representative bodies of power through elections.

Hence, the electoral function, along with other functions of political parties, is understood as one of the important areas of activity in achieving their socio-political role, goals and objectives. The electoral function of political parties is interrelated with their other functions and operates through interaction.

In carrying out these tasks, not only political parties and civil society institutions, but also every citizen, civil servant must feel a great responsibility to himself [13].

Another task related to the content of the electoral function is to cultivate human resources, ie to form a circle of candidates for the party's representative bodies, to elect and encourage them, to prepare them for public administration, to systematically organize the acquisition of necessary knowledge and skills. .

In other words, cadres for modern parties are not trained in special universities or retraining courses. Based on its ideas and views, the party seeks and educates politicians who will serve to develop it in the future. In short, the party is an important institution for personnel development.

In addition to the above, the electoral function of political parties includes the following tasks: campaigning, nominating candidates, collecting voters' signatures, preparing election platforms, conducting pre-election and post-election campaigning, monitoring the voting process and summarizing election results. According to some experts, most of the modern party systems in developed countries have an "electoral function". While fully supporting this view, it should be noted that the misconception that political parties perform their functions only in the electoral process has not worked.

There are countries that emphasize the electoral function in the classification of the 
functions of political parties [14. P. 74]. For example, the scientific literature on the analysis of the functions of parties in the United States classifies functions such as communicative, unifying, as well as participation in the electoral process, holding seats in the representative body of state power through elections, and participation in the exercise of state power through their representatives.

Some experts point out three main functions of the party: the formation of public opinion, the selection of candidates for elected state bodies and the creation of conditions for the activities of deputies [15. P. 2].

It should be noted that all of the above functions are performed by parties in a complex way and sometimes in practice it is difficult to separate them, the measures to implement them are closely interrelated, often intersecting and encompassing each other.

Taking into account the above approaches, it is expedient to understand the participation of political parties in the electoral process, ie the electoral function - the implementation of the rights and obligations of political parties in the field of electoral relations through certain electoral procedures, actions, tools and forms.

Only by winning elections and gaining seats in the representative body of power can a party legally gain power and achieve its programmatic goals. Victory in elections is a key condition for the successful operation of the party, a measure of its effectiveness and vitality. These results cannot be achieved without effective use of the electoral functions of political parties.

Thus, the electoral function has a special place in the activities of parties. In some literatures, this function is also called a structural function. This is the function of the party aimed at developing the electoral strategy, promoting the election platform, nominating candidates.

The electoral function has a mass character, so its implementation is not only a right but also an obligation of political parties. Today, in many democracies around the world, there is a tendency for electoral legislation to focus on strengthening the status of political parties, seeking to regulate their activities in detail at each stage of the electoral process.

In order for our analysis to be comprehensive and systematic, we consider it expedient to focus on the national legal framework of the electoral function of parties.

According to Article 1 of the Law of the Republic of Uzbekistan "On Political Parties", a political party is formed on the basis of common views, interests and goals of citizens of the Republic of Uzbekistan and is a voluntary association.

In our opinion, this definition of legislation does not sufficiently reflect the electoral function, which is an important function of the party, because it is this function that leads to the official struggle for state power.

In accordance with Article 12 of the Law "On Political Parties": "Political parties have the right to participate in the elections of the President of the Republic of Uzbekistan, public authorities in the manner prescribed by law." Hence, the legislature has indirectly strengthened the electoral functions of all public associations with the status of political parties. In this regard, we support the idea that participation in the struggle for state power through elections should be enshrined in law as a key feature of a political party. 
We also consider it expedient to improve the mechanism of legal regulation of electoral relations. At the same time, we envisage a system of all organically organized legal instruments that can be adopted, the use of which will ensure an effective special legal effect on electoral relations. These legal mechanisms cover all important aspects of the electoral process.

It follows that one of the main tasks of a political party is to organize and conduct an election campaign. Therefore, participation in elections is not only the main task of a political party, but also a social duty. Unfortunately, neither the Law of the Republic of Uzbekistan "On Political Parties" nor the Electoral Code stipulate that participation in elections is a legal obligation of a party.

Therefore, we consider it expedient to supplement Article 1 of the Law "On Political Parties" with a provision on the mandatory participation of parties in elections. At the same time, if a party does not participate in the election campaign for a certain period of time, we advice to strengthen the norm in the law that it can remain an ordinary public association and lose the status of a political party.

Thus, the electoral function of the party, as one of the leading directions of its activities, has a multifaceted nature, and its implementation in various forms and methods is regulated in detail in the legislation. Participation in the election process is an embodiment of the social nature of political parties and their political and legal role in the mechanism of people's power. Therefore, the electoral function should be legally strengthened in the legislation in the organizational and legal mechanism of the exercise of the right of parties to participate in elections.

Another important issue is that the formation of the electoral legal culture of the electorate is a very important component of the electoral function of political parties.

An important aspect of the legal culture of the electorate is the rational use of all opportunities created in the polling stations with justice, fairness and responsibility, feeling that the elections are a test of deep understanding, deep thinking and knowledge for each voter. There should be no room for superficiality, indifference, indifference and falsity in this regard, on the contrary, every citizen should have a sense of responsibility for the fate of the country, involvement in reforms.

In conclusion, it should be noted that elections are an important form of participation of political parties in the formation of representative bodies of state power. At the same time, the parties implement their electoral policy by organizing various events in support of their candidates.

The success of the electoral function is a basic condition for the existence and functioning of a political party, an indicator of the effectiveness and vitality of its activities. After all, in the eyes of voters, the party can get a positive or negative assessment of the election results. The results of this function allow to determine the level of voter confidence in a particular party, a candidate. 


\section{REFERENCES}

1. Schlesinger, J.A., 1994. Political parties and the winning of office. University of Michigan Press. - P. 3.

2. Mersel Y. The dissolution of political parties: The problem of internal democracy //International journal of constitutional law. - 2006. - T. 4. - №. 1. C. 84-113.

3. Wigton R. C. The Parties in Court: American Political Parties Under the Constitution. - Lexington Books, 2013.

4. Fombad C. M. Challenges to constitutionalism and constitutional rights in Africa and the enabling role of political parties: Lessons and perspectives from Southern Africa //The American Journal of Comparative Law. - 2007. - T. 55. - №. 1. C. 1-45.

5. Gabryszak R. et al. The evolution of the positions on social issues of major political parties in Poland. Comparative analysis of the election programs of Platforma Obywatelska (Civic Platform) and Prawo i Sprawiedliwość (Law and Justice) from 2007, 2011 and 2015 //Przegląd Politologiczny. - 2019. - №. 4. - C. 95-108.

6. Heath O., Ziegfeld A. Electoral volatility and turnout: Party entry and exit in Indian Elections //The Journal of Politics. - 2018. T. 80. - №. 2. - C. 570-584

7. Deschouwer K. Political Parties as Organizations: A Contingency Approach. Paper delivered at the World Conference of the International Sociological Association. 1986. - P. 6.

8. Janda K. Political Parties: A Cross-National Survey. N. Y.: The Free Press, 1980. LIX. P. 32.
9. Volkova E.A. Constitutional and legal aspects of the participation of political parties in the formation and activity of the parliament of Russia: abstract of diss. cand.law sciences. - M., 2010. - P. 6. (Волкова Е.А. Конституционноправовые аспекты участия политических партий в формировании и деятельности парламента России: автореф. дисс. .... канд.юрид.наук. - М., 2010. - С. 6.)

10. Berlin P. A. Political parties in the West: their doctrines, organization and activities. SPb., 1997. - P. 5. (Берлин П. А. Политические партии на Западе: их доктрины, организация и деятельность. СПб., 1997. - С. 5.)

11. Lawson K. The Comparative Study of Political Parties. N. Y.: St. Martin's Press, 1976. XIII. - P. 3-4.

12. Taagepera R., Shugart M.S. Description of electoral systems // Polis. 1997. No. 3. S. 114-137; Lakeman E., Lambert J.D. Research of majority and proportional electoral systems / ed. Shugaeva A.S. M., 1958. (Таагепера P., Шугарт M.C. Описание избирательных систем // Полис. 1997. №3. С.114-137; Лейкман Э., Ламберт Дж.Д. Исследование мажоритарной и пропорциональной избирательных систем/ под ред. Шугаева А.С. М., 1958.)

13. Botirov Khurshid. Problems of Constitutionalism in Uzbekistan //Review of law sciences. - 2020. - Vol. 3. - №. Special Issue.

14. Sogrin V.V. The bipartisan system of the United States: continuity and renewal // Political Studies. - 2003. - No. 3. - S. 164-170; A.E. Nevakshenov Party problems of the United States in American historical and political thought of the second half of the 
Doi: https://doi.org/10.37547/tajpslc/Volume03Issue04-17

twentieth century: author. diss. ...cand.

historical sciences. - Tomsk, 2008 .- P. 23.

(Согрин В.В. Двухпартийная система

США: преемственность и обновление //

Политические исследования. - 2003. - №

3. - С. 164-170; Невакшенов А.Е. Партийная проблематика США в американской историко-политической мысли второй половины $\mathrm{xx}$ века: автореф. дисс. ......канд. истор. наук. Томск, 2008. - С. 23.)

15. Katz R. A Theory of Parties and Electoral Systems / Baltimore : The John Hopkins University Press, 2007. - P. 74.

16. Safarova H. Improvement of the constitutional and legal guarantees of ensuring the right of citizens to qualified health care in Uzbekistan //Review of law sciences. - 2020. - Vol. 5. - №. Special Issue. 